Jurnal Keperawatan Silampari

Volume 2, Nomor 1, Desember 2018

e-ISSN : 2581-1975

p-ISSN : 2597-7482

DOI: https://doi.org/10.31539/jks.v2i1.306

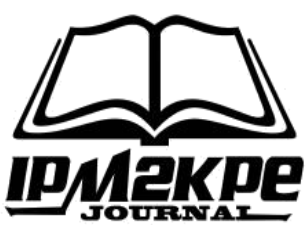

\title{
PENGARUH METODE GLENN DOMAN (TAHAP 1 DAN 2) TERHADAP PERKEMBANGAN KOMUNIKASI ANAK AUTISME
}

\author{
Haifa Wahyu ${ }^{1}$, Betrianita ${ }^{2}$, Melati Tridita Pramesti ${ }^{3}$, Padila $^{4}$ \\ Program Studi Ilmu Keperawatan, Universitas Muhammadiyah Bengkulu ${ }^{1,3,4}$ \\ Program Studi Kesehatan Masyarakat, Universitas Muhammadiyah Bengkulu ${ }^{2}$ \\ haifaw10@gmail.com ${ }^{1}$
}

\begin{abstract}
ABSTRAK
Penelitian ini bertujuan untuk mengetahui pengaruh metode glenn doman tahap 1 dan 2 terhadap perkembangan komunikasi berfikir anak autisme di Autis Center Bengkulu. Desain penelitian yang digunakan adalah quasi experiment, dengan rancangan yang digunakan adalah two group before after atau pre-test and post test group design. Hasil penelitian menunjukkan bahwa pada analisa univariat diketahui mayoritas usia responden 3-4 tahun dengan jenis kelamin mayoritas laki-lak dengan kemampuan bicara pada kelompok kontrol maupun kelompok perlakuan sebelum diberi terapi glenn doman tahap 1 dan 2 adalah cukup mampu. Dan perkembangan komunikasi pada kelompok perlakuan mayoritas meningkat menjadi mampu. Pada analisa bivariat diketahui nilai $\mathrm{p}$ v $0,000<0,05$. Simpulan, ada pengaruh signifikan terapi glenn doman tahap 1 dan 2 terhadap perkembangan komunikasi anak autisme di Autis Center Bengkulu.
\end{abstract}

Kata Kunci: Autisme, Glenn Doman

\begin{abstract}
This study aims to determine the effect of the Glenn Doman methods stages 1 and 2 on the development of thinking communication in children with autism at the Bengkulu Autism Center. The research design used was quasi experiment, with the design used was two groups before after or pre-test and post test group design. The results showed that in the univariate analysis the majority of respondents aged 3-4 years with the majority of male sex with the ability to speak in the control group and the treatment group before being given glenn doman therapy stages 1 and 2 were quite capable. And the development of communication in the majority treatment group increased to be able. In bivariate analysis, it was known that the value of $p v 0,000<0.05$. Conclusion, there is a significant influence of stage 1 and 2 glenn doman therapy on the development of communication of children with autism at Bengkulu Autis Center.
\end{abstract}

Keywords: Autism, Glenn Doman 


\section{PENDAHULUAN}

Menurut Kemenkes (2010) tumbuh kembang merupakan sebuah kesatuan yang mencerminkan perubahan-perubahan yang terjadi pada seseorang sepanjang fase kehidupannya. Proses pertumbuhan dan perkembangan setiap anak tentu berbeda-beda dan memiliki kekhasan sendiri-sendiri. Permasalahan yang dihadapi juga tidak sama dari antara masing-masing anak. Permasalahan yang terjadi dapat berasal sejak kelahiran anak seperti salah satunya pada anak-anak yang terlahir kurang bulan (prematur) dimana predisposisi dari persalinan preterm yaitu: adanya riwayat persalinan preterm masa lalu, kelainan pada amnion, infeksi saluran kemih, hamil kembar, gangguan uterus, faktor biological, adanya riwayat perdarahan, ibu yang mengalami hipereklapmsia dan riwayat diabetes gestasional, alat kontrasepsi masih didalam rahim, penyakit resus, kematian fetus, sosial ekonomi, tekanan psikologis dan kebudayaan yang dianut (Manuaba, Ida, B.G, dkk. 2007 dalam Padila, P., Amin, M., \& Rizki, R, 2018) faktor lainnya yang dapat menyebabkan terjadinya perkembangan anak ke arah autisme yaitu faktor ibu dimana saat kehamilnya mengalami anemia, Hasil penelitian Ridayanti (2012) dalam Mariana, D., Wulandari, D., \& Padila, P. (2018) menyebutkan bahwa ibu hamil dengan anemia berat juga dapat mengakibatkankelahiran autisme, Sehinga perkembangan anak sangat beresiko mengalami gangguan pada tahap perkembangan fisik, mental, emosi, sosial, dan intelegensi. Beberapa kelompok anak yang mengalami gangguan tumbuh kembang yaitu retardasi mental, tuna laras, tuna daksa, dan autisme (Mariana, D., Wulandari, D., \& Padila, P, 2018).

Terdapat angka yang bervariasi pada data anak-anak yang menderita autisme di berbagai belahan dunia. Data dari UNESCO melaporkan bahwa terdapat 35 juta orang penyandang autisme di seluruh dunia pada tahun 2011, itu artinya setiap 1000 orang, terdapat 6 orang yang telah mengidap autisme di seluruh dunia. Pada penelitian CDC (Center for Disease Control) di Amerika, diperoleh informasi bahwa anak umur 8 tahun yang terdiagnosa dengan autisme adalah $1: 80$ pada tahun 2008. Dalam penelitian di Hongkong Study tahun 2008 melaporkan tingkat prevalensi 1,68 per 1.000 untuk anak di bawah 15 tahun. Sedangkan berdasarkan data World Health Organization (WHO) tahun 2015 menunjukkan bahwa terdapat peningkatan jumlah penderita autisme dari tahun ke tahun. Sepuluh tahun yang lalu jumlah penyandang autisme diperkirakan satu per 5.000 anak, tahun 2000 meningkat menjadi satu per 500 anak". Diperkirakan tahun 2010 satu per 300 anak. Sedangkan tahun 2015 diperkirakan satu per 250 anak. Tahun 2015 diperkirakan terdapat kurang lebih 12.800 anak penyandang autisme atau 134.000 penyandang spektrum Autisme di Indonesia (WHO, 2015).

Sampai saat ini belum diketahui berapa orang jumlah konkret penyandang autisme di Indonesia, namun berdasarkan data yang dikeluarkan oleh Badan Pusat Statistik (BPS), diperoleh informasi bahwa pada tahun 2016 jumlah penderita autisme diperkirakan mencapai 2,4 juta orang. Jumlah penduduk Indonesia mencapai 237,5 juta pada tahun tersebut dan laju pertumbuhan 1,14 persen. Jumlah penderita autisme diperkirakan mengalami penambahan sekitar 500 orang setiap tahun di Indonesia. Jumlah kasus autisme mengalami peningkatan yang signifikan (Kemenkes, 2015).

Autisme merupakan masalah yang amat kompleks bagi perkembangan anak, yang mengakibatkan anak autisme sulit menyesuaikan diri dengan lingkungan sekitar. Anak autisme terbagi dalam tiga komponen yaitu ringan, sedang dan berat. (Setiati, 2012). Salah satu gangguan yang dialami oleh anak autisme adalah ketidakmampuannya dalam berkomunikasi atau berbincang dengan orang lain, sekalipun dengan keluarga terdekatnya sendiri. Anak autisme bersikap seolah-olah tidak mendengar/tuli, berbicara 
acak tanpa arti, meniru ucapan orang lain, menikmati kehidupan dalam dunianya sendiri, atau dunia khayalan, seakan-akan hanya mereka sendiri yang ada dalam lingkungan hidup disekitarnya. Sebagian besar anak autisme mengalami gangguan bicara dan berbahasa, ada anak yang dapat berbicara lancar tetapi tidak dapat berkomunikasi, dapat berbicara tetapi dengan kemampuan terbatas, dan tidak dapat berbicara sama sekali. Maka dari itu dalam upaya meningkatkan kemampuan berbahasa dan berkomunikasi pada anak autisme diperlukan pemberian stimulasi.

Asumsi sebagian besar masyarakat menganggap bahwa anak abnormal akan disebut sebagai anak cacat. Pada dasarnya, tidak ada anak yang terlahir abnormal melainkan anak dengan kebutuhan khusus. Anak-anak penderita autisme tersebut sama seperti anak normal lainnya yang pada umumnya pun juga memiliki kekurangan. Oleh karena itu, perlu dijelaskan kepada masyarakat bahwa anak yang memiliki keterbatasan yang terdapat pada fisik mereka ternyata juga memiliki hak yang sama dengan anak normal pada umumnya. Pemerintah juga memberikan hak yang sama kepada seluruh warga Indonesia termasuk hak untuk mendapatkan kesempatan pendidikan sebagaimana tertuang dalam UU tentang pendidikan Bab IV pasal 5 ayat 2: "warga negara yang memiliki kelainan fisik, emosional, mental, intelektual, atau sosial berhak memperoleh pendidikan khusus. Berbagai kelainan fisik, emosional, mental, dan intelektual yang dialami anak diantaranya adalah anak-anak autisme.

Penatalaksanaan yang terpadu harus secepat mungkin dilaksanakan bila diagnosis autisme sudah tertegak. Meskipun kelainan yang ada di otak tidak dapat disembuhkan seratus persen, namun dengan program tatalaksana yang terpadu dan intensif, dapat mengurangi bahkan menghilangkan gejala-gejala autisme, sehingga ia diharapkan bisa berbaur dan hidup mandiri dalam masyarakat yang normal.

Penanganan terbaik bagi anak autis adalah yang melibatkan berbagai macam disiplin ilmu, yakni psikologi, kedokteran, dan pendidikan khusus. Idealnya orang tua memiliki tim yang memahami anak dan bersama-sama mengembangkan penangan terpadu dan terus berkembang sejalan dengan usia anak. Tim tersebut adalah orang tua dan terapis, diantara mereka harus terjalin komunikasi yang baik. Guru ideal adalah guru yang dapat mengaktualisasikan ilmu pengetahuan dan kemampuan, memiliki empati, ada kesadaran bahwa ilmu yang dimilki adalah hak anak (Adriana, 2010).

Anak-anak autisme dapat diajari membaca sebagaimana halnya anak-anak normal. Standar kompetensi dan kompetensi dasar anak-anak autisme dapat disusun oleh sekolah agar disesuaikan dengan keadaan anak-anak didik dan sarana prasarana pembelajaran yang tersedia. Bahan ajar dapat disesuaikan secara mandiri dan leluasa oleh guru, sesuai dengan kondisi sekolah dan kemampuan anak-anak autisme tersebut.

Pada metode Glenn Doman, anak diperagakan gambar tulisan berupa kata sederhana tentang benda-benda disekitar mereka. Metode ini telah dicobakan pada anak-anak yang cedera otak (Cerebral Palsy) yang dilakukan oleh Noviani Pertamawati tahun 2007 yang berjudul "Penerapan Metode Glen Doman untuk Meningkatkan Kemampuan Membaca Anak Cerebral Palsy”. Cerebral Palsy adalah anak-anak yang mengalami kelumpuhan otak. Peneliti Sigmun Freud menyatakan bahwa anak cerebral palsy dikategorikan cenderung mengalami retardasy mental, sebagaimana halnya anak autisme.

Konsep pengajaran berdasarkan tingkat perkembangan otak anak diperkenalkan oleh Glenn Doman, ia dikenal sebagai pendiri Institute for the Achievement of Human Potential (IAHP). Metode Glenn Doman yang berawal dari konsep pengajaran membaca bagi anak bayi sangat cocok dengan anak autisme yang mengalami 
keterlambatan perkembangan membaca.Menurut Glenn Doman, metode pengajaran konvensional sangat membatasi semangat anak untuk mempunyai kemampuan pengetahuan dan skill yang lain. Berdasarkan usia, anak memang masih memiliki keterbatasan yang tak dapat dipaksakan. Misalnya, jika orang dewasa berkata dengan pelan, maka anak usia setahun tidak akan memberi respons karena pendengaran belum cukup berkembang untuk menangkap bisikan itu atau anak tak bisa membaca jelas karena kemampuan penglihatannya belum sempurna untuk melihat huruf kecil. Sebaiknya gambar yang diperlihatkan kepada anak adalah gambar yang besar dengan warna yang terang. Metode Glenn Doman ini dilaksanakan dengan menggunakan flashcards yang disertai petunjuk. Sangat baik bagi anak usia 10-18 bulan. Glenn Doman yang telah puluhan tahun meneliti perkembangan otak anak, khususnya anak yang terkena cedera otak. Dia mengatakan bahwa otak anakmasih bisa mempunyai kemampuan sama dengan anak dengan otak utuh, bahkan sekalipun yang sudah dibedah hemisferektomi (dibuang setengah fisik) otaknya.

Surana (2008) mengatakan bahwa stimulasi merupakan suatu proses pemberian rangsangan untuk meningkatkan kemampuan dasar yang dimiliki oleh anak terutama untuk meningkatkan perkembangan pada anak baik perkembangan bahasa maupun kognitif. Stimulasi sangat penting diberikan sebagaisarana untuk menghubungkan selsel otak yang belum terhubung satu sama lain). Salah satu stimulasi atau terapi yang dilakukan pada anak autism dapat berupa terapi medikamentosa dan non medikamentosa. Tujuan terapi autisme adalah untuk mengurangi masalah perilaku dan meningkatkan kemampuan belajar dan perkembangannya terutama dalam penguasaan bahasa. Penderita autisme yang dideteksi dini serta langsung mendapat perawatan dapat hidup mandiri tergantung dari jenis gangguanautismetik umur saat terdeteksi dan ditangani (Made, 2014). Salah satu penanganan terapi dalam mengatasi gangguan komunikasi pada anak autisme adalah terapi wicara.

Karena semua pengidap autisme mempunyai keterlambatan bicara dan kesulitan berbahasa sehingga terapi wicara menjadi suatu keharusan bagi penderita autisme. Penerapan metode glenn doman menjadi salah satu terapi wicara yang sering digunakan pada anak autisme dengan gangguan komunikasi. Metode glenn doman sangat digemari oleh masyarakat kita dalam mengajarkan putra-putri mereka membaca diusia yang sangat dini. Metode glenn doman menjadi salah satu metode belajar membaca pada balita dan sering digunakan pada autisme center dalam memberikan terapi wicara pada anak autisme. Pada penerapan terapi glenn doman dilakukan dalam waktu singkat hal ini dikarenakan mencegah kebosanan pada anak. Perasaan mudah bosan merupakan salah satu ciri anak. anak mempunyai tingkat konsentrasi dan perhatian yang pendek (Suyanto, 2008). Cara mengatasai kebosanan pada anak adalah menciptakan kegiatan belajar yang variatif dan perlu diganti setiap 10 - 15 menit. Penggunaan waktu yang singkat membuat pelaksanaan metode glenn doman dalam kelompok eksperimen dirasakan lebih efektif. Guru memerlukan waktu yang relatif lebih singkat dan energi yang lebihringan untuk mengenalkan kata-kata yang ingin dikuasai oleh anak. Kegiatan anak menyimakkata-kata, misalnya 5 kata tunggal yang pertama seperti mama, papa, adik, kakak, dan saya,durasi yang digunakan untuk sesi ini berkisar 15 - 18 detik setiap anak.

Mirza (2010) mengatakan bahwa autisme sebenarnya sangat perlu menjadi perhatian khusus, ada beberapa prinsip-prinsip penanganan penderita autisme : Pertama, Urgensimencintai dan menerima.sikap menerima dan mencintai adalah yang terpenting untuk memenuhi atau membuka hubungan dengan anak-anak berkebutuhan khusus. 
kunci keberhasilan dari program ini adalah sikap tidak menghakimi dan menilai anak, seperti dalam pendidikan formal lainnya. Kedua, Menghakimi atau menilai. Diharapkan jangan menghakimi anak kita dengan mengatakan bahwa yang dilakukan anak ini benar atau salah ataupun baik atau buruk. Terapis atau orang tua atau siapapun yang ingin membantu anak kita, berusahalah untuk mempelajari dan memasuki dunia anak serta mendorong timbulnya suatu ikatan yang spesial dan penuh cinta. Berusahalah untuk bersikap baik, dan timbulkan keinginan anak untuk ingin tahu lebih lanjut dan belajar banyak dari kita. Anak kita adalah titipan dari Tuhan, dan Tuhan telah menunjuk kita sebagai orang tua yang diberi anugerah anak spesial, maka kita harus memberikan perhatian yang spesial kepadanya, juga pendidikan dan keistimewaan dalam mengurus dia. Itulah moto yang harus dipegang oleh para orang tua. kita tidak akan dapat menghargai dan menerima kehadiran anak itu dalam lingkungan keluarga kita jika kita menganggap bahwa anak autisme sebagai musibah dan kutukan,

Dengan berbagai pandangan dari option institute, yang salah satunya mengatakan "You have a special child so God ask you to treat him/her specially, give them a special treatment". Dengan adanya moto tersebut, akan mendorong kita untuk memberikan energi dan dedikasi dalam menolong anak kita, dan memberikan respons dengan penuh rasa cinta serta mencari sesuatu cara untuk membantu anak kita. Orang tua sumber terbaik anak (The Chil's Best Resource) Orang tua adalah penolong dan pembimbing yang paling baik dan berdedikasi tinggi. orang tuanya sendirilah yang dapat menyelami dunia anaknya. Hal ini sering diabaikan dan diacuhkan oleh para profesional.Para profesional mengenal anak kita hanya beberapa jam sehari. Tetapi sebagai orang tuanya, sisa dari waktu belajar anak secara rutin ada di rumah, di lingkungan keluarga (orang tuanya). Karena itu, dalam hal ini yang paling mengetahui keistimewaan anak adalah orang tua itu sendiri. Pertanyaan tentang harapan dan harapan yang salah. Apakah harapan untuk mengembangkan dan menolong anak kita tersebut adalah harapan kosong/ salah? Apakah kita mematikan harapan itu? Salah satu dari prinsip pendiri Option Institute yang sangat menguatkan kita adalah : Tiada salahnya kita mempunyai harapan selama anak itu masih ada nafas (hidup). Karena dengan mengabaikan dan menutup harapan yang salah (false hope), berarti mengabaikan hasil kerja mereka dan menutup pintu untuk membantu orang lain.Sebagai orang tua, lebih baik kita berkata : Biarkan saya mencoba membantu anak saya walau apa pun yang dikatakan orang lain, walaupun hasil yang terbukti dari orang lain menyedihkan. Tapi saya ingin melakukan yang terbaik, dengan penuh cinta, dan menerima anak saya apa adanya. Anak sebagai guru. Pada program yang disarankan oleh option institute untuk mengajar anak, yaitu dengan cara menarik informasi, pengertian dan pandangan dari mereka, membantu mereka untuk mengembangkan dan membangun bakat mereka sendiri, keterampilan dan minatnya, memperkenalkan situasi belajar di mana mereka dapat mencari sendiri secara bebas, dan membantu mereka setelah keingintahuan dan keinginsertaan mereka berkembang.

Pertamawati (2008) seperti halnya beberapa peneliti mengatakan dunia anak adalah dunia bermain. Ia menyatakan bahwa metode membaca yang diajarkan glenn doman merupakan suatu metode belajar dengan bermain dan belajar, begitu pula yang diterapkan dalam metode ini ialah dunia anak yaitu dunia bermain dengan belajar. Penelitian berjudul "peran glenn doman sebagai metode pembelajaran membaca pada anak yang mengalami cedera otak" dilaksanakan oleh Rohman (2010) dimana hasil penelitian ini menunjukkan bahwa kemampuan membaca antara subjek pertama dengan subjek kedua berbeda. Subjek yang mengalami retardasi mental menunjukkan kognitif 
yang lebih baik karena subjek kedua dapat menyebutkan 8 kata dari setiap 10 kata yang diberikan oleh peneliti. Selain itu penelitian yang dilakukan Tiara (2013) dengan judul "pengaruh metode glenn doman terhadap perkembangan bahasa dan kognitif anak usia prasekolah di TK. Ladas Berendai Prabumulih" dengan hasil yang menunjukkan metode glenn doman dapat meningkatkan perkembangan bahasa dan kognitif anak.

Berdasarkan data dari profil kesehatan Bengkulu didapatkan data penyandang autisme di kota Bengkulu terus meningkat. Salah satu lembaga yang memberikan penanganan anak-anak penyandang autisme di Provinsi Bengkulu adalah Autis Center. Autis Center merupakan sekolah untuk anak-anak yang berkebutuhan khusus terbaik dan terlengkap sarana dan prasarananya dibanding sekolah lain di Kota Bengkulu. Autis Center memiliki program-program yang terstuktur dalam menangani dan mendidik siswa-siswi nya. Untuk mengatasi masalah komunikasi pada anak autisme, Autis Center memiliki program terapi wicara.

Berdasarkan survey awal pada tanggal 4 April 2017, data yang diperoleh di Autis Center Bengkulu, pada bulan bulan Januari-Desember 2016 diketahui penyandang autisme terbanyak adalah usia 4-7 tahun yang berjumlah 28 orang, terdiri dari 13 anak perempuan dan 15 anak laki -laki, sedangkan pada bulan Januari sampai Februari 2017 menjadi 21 anak autisme, dan pada bulan Maret 2017 terakhir bertambah 14 anak menjadi 35 anak autisme. Berdasarkan hasil observasi dan pengamatan peneliti diketahui 11 anak dengan usia 6-10 tahun keterampilan berkomunikasi dan berpikirnya sudah baik dan 21 anak dengan usia 2-5 tahun keterampilan berkomunikasi belum baik, karena 21 anak tersebut mengalami jenis autismaloof (menarik diri dari kontak sosial dan cenderung untuk menyendiri di pojok) dan tidak rutin mengikuti terapi glenn doman. Hasil survey awal juga menunjukkan bahwa 21 anak autisme dengan usia 2-5 tahun tersebut terdiri dari 18 orang dengan autisme tingkat ringan dan 3 orang mengalami autisme tingkat sedang. Anak autisme dengan tingkatan sedang masih mau meniru hal atau perilaku yang sederhana, masih mau mendengar sesuatu yang disukainya.

Selain itu dari hasil wawancara, terapis autis center menyatakan bahwa terapi wicara yang dilaksanakan dapat meningkatkan kemampuan berbahasa anak autisme namun belum diketahui seberapa besar pengaruhnya terhadap kemampuan perkembangan komunikasi pada anak autism.

Berdasarkan latar belakang dan hasil survey pendahuluan yang telah dilakukan sebelumnya, diketahui bahwa di Autis Center terapi yang digunakan dalam meningkatkan perkembangan bahasa anak autisme menggunakan terapi wicara sambil bermain kartu flash card. Tujuannya agar diketahui efektivitas terapi metode glenn domantahap 1 dan 2 terhadap perkembangan komunikasi pada anak autisme di Autis Center Kota Bengkulu

\section{METODE PENELITIAN}

Desain penelitian yang digunakan adalah quasi experiment, dengan desain eksperimen yang digunakan adalah two group before after atau pre-test and post test group design. Rancangan ini terdiri dari satu kelompok eksperimen yang diberi perlakuan berupa penerapan model dan satu kelompok kontrol. Populasi dalam penelitian ini adalah seluruh anak autisme di Autis Center Bengkulu yang diterapi perilaku metode Glenn doman yang berjumlah 30 orang. Pada penelitian ini, sampel yang diambil sebanyak 15 orang pada masing-masing kelompok yaitu kelompok perlakuan dan kelompok kontrol 
dengan pertimbangan sampel yang aktif dan rutin mengikuti terapi glenn doman sebanyak 30 orang dan jumlah tersebut dianggap sudah mewakili populasi.

Ada beberapa metode pengumpulan data yang digunakan dalam penelitian ini. Pengumpulan data primer dilakukan secara langsung dilapangan dengan menggunakan kuisioner untuk mengukur kemampuan komunikasi anak autisme. Sedangkan data sekunder diperoleh dari instansi-instansi terkait yang ada hubungannya dalam penelitian ini. Pada penelitian ini, peneliti melakukan eksperiment terhadap anak autisme di Autisme Center Bengkulu dimana sebelumnya peneliti mengukur kemampuan berkomunikasi pada kelompok kontrol dan kelompok perlakuan sebelum diberi terapi glenn doman (pre test). Selanjutnya peneliti memberikan terapi glenn doman setelah itu peneliti melakukan pengukuran ulang terhadap kemampuan berkomunikasi anak autisme sesudah diberikan terapi (post test). Untuk lebih jelasnya metode yang penulis gunakan dalam pengumpulan data pada penelitian ini adalah :

\section{Observasi (Pengamatan)}

Metode ini dilakukan untuk mendapatkan data primer yang dilaksanakan pada awal penelitian dengan tujuan untuk mendapatkan gambaran tentang keadaan permasalahan yang akan diteliti, yang kemudian dijadikan petunjuk dan arah dalam pelaksanaan penelitian. Pada penelitian ini, peneliti melakukan eksperiment terhadap anak autisme di Autisme Center Bengkulu dimana sebelumnya peneliti mengukur kemampuan berkomunikasi pada kelompok kontrol dan kelompok perlakuan sebelum diberi terapi glenn doman (pre test).Selanjutnya peneliti memberikan terapi glenn doman setelah itu peneliti melakukan pengukuran ulang terhadap kemampuan berkomunikasi anak autisme sesudah diberikan terapi (post test).

\section{Kuisioner (daftar Pertanyaan)}

Metode ini dilakukan untuk mendapatkan data primer secara langsung dari responden. Kuisioner untuk mengukur kemampuan berkomunikasi anak autisme.

Pengolahan data

Editing. Dilakukan untuk memeriksa ulang kelengkapan data yang terkumpul apakah telah sesuai dengan yang diharapkan.

Coding. Coding merupakan pemberian kode terhadap data atau mengubah keterangan dalam bentuk angka dengan tujuan untuk mempermudah dalam analisa data.

Entry, data tersebut dimasukkan kedalam master tabel setelah dilakukan coding, menurut sifat - sifat yang dimiliki sesuai tujuan peneitian dengan menggunakan komputerisasi dengan program SPSS.

Cleaning, proses ini yaitu memeriksa kembali data yang sudah diproses apakah ada kesalahan atau tidak pada masing - masing variabel yang sudah diproses sehingga dapat diperbaiki dan dimulai. 


\section{HASIL PENELITIAN}

Hasil penelitian menunjukkan bahwa pada analisa univariat diketahui mayoritas usia responden 3-4 tahun dengan jenis kelamin mayoritas laki-laki dengan kemampuan bicara pada kelompok kontrol maupun kelompok perlakuan sebelum diberi terapi glenn doman tahap 1 dan 2 adalah cukup mampu. Dan perkembangan komunikasi pada kelompok perlakuan mayoritas meningkat menjadi mampu.

Tabel. 1

Karakteristik Responden Berdasarkan Umur

\begin{tabular}{clcc}
\hline No & Umur & Frekuensi & Persentase \\
\hline & Kelompok Kontrol & & \\
\hline 1 & 2 tahun & 1 & 6,7 \\
2 & 3 tahun & 7 & 46,7 \\
3 & 4 tahun & 5 & 33,3 \\
4 & 5 tahun & 2 & 13,3 \\
\hline & Total & 15 & 100 \\
\hline & Kelompok Terapi & & 40,0 \\
\hline 1 & 3 tahun & 6 & 46,7 \\
2 & 4 tahun & 7 & 13,3 \\
3 & 5 tahun & 2 & 100 \\
\hline
\end{tabular}

Berdasarkan tabel diatas, diketahui bahwa sebagian besar anak autisme pada kelompok perlakuan $(46,7 \%)$ atau 7 orang responden berusia 4 tahun, hampir sebagian $(40 \%)$ atau 6 orang berusia 6 tahun dan hanya sebagian kecil $(13,3 \%)$ atau 2 orang yang berusia 5 tahun. Sedangkan pada kelompok kontrol diketahui hampir sebagian $(46,7 \%)$ responden berusia 3 tahun, anak autisme yang berusia 4 tahun sebanyak 33,3\%, berusia 5 tahun sebanyak 13,3\% dan anak autisme berusia 2 tahun sebanyak 6,7\%.

Karakteristik responden pada penelitian ini menurut jenis kelamin dapat dilihat pada tabel berikut ini :

Tabel. 2

Karakteristik Responden Berdasarkan Jenis Kelamin

\begin{tabular}{cccc}
\hline No & Jenis Kelamin & Frekuensi & Persentase \\
\hline & Kelompok Kontrol & & \\
\hline 1 & Perempuan & 6 & 40,0 \\
2 & Laki-laki & 9 & 60,0 \\
\hline & Total & 15 & 100 \\
\hline 1 & Perempuan & 3 & 20,0 \\
2 & Laki-laki & 12 & 80,0 \\
\hline & Total & 15 & 100 \\
\hline
\end{tabular}

Berdasarkan pada tabel diatas diketahui bahwa pada penelitian ini jenis kelamin pada kelompok perlakuan sebagian besar $(80 \%)$ atau 12 orang responden berjenis kelamin laki-laki dan hanya sebagian kecil (20\%) atau 3 orang berjenis kelamin perempuan. Sedangkan pada kelompok kontrol diketahui sebagian besar (60\%) anak autisme berjenis kelamin laki-laki dan sisanya $40 \%$ berjenis kelamin perempuan. 
Tabel. 3

Distribusi Frekuensi rata-rata Kemampuan Bicara

Pada Kelompok Kontrol dan Kelompok Perlakuan Sebelum dan Sesudah Terapi Glenn Doman Tahap 1 dan 2

\begin{tabular}{ccccc}
\hline Kelompok & Mean & Min-max & Standar Deviasi & Standar Error \\
\hline \multicolumn{3}{c}{ Kelompok Kontrol } & & \\
\hline Pre Test & 8,67 & $4-12$ & 2,257 & 0,583 \\
Post Test & 8,87 & $5-12$ & 1,995 & 0,515 \\
\hline \multicolumn{5}{c}{ Kelompok Perlakuan } \\
Post Test & 14,53 & $12-17$ & 1,552 & 0,401 \\
\hline
\end{tabular}

Berdasarkan tabel diatas diketahui rata-rata kemampuan bicara anak-anak autis sebelum diberi terapi glenn doman tahap 1 dan 2 adalah sebesar 14,53 dan setelah mendapatkan terapi glenn doman tahap 1 dan 2, kemampuan bicara anak autis mengalami peningkatan menjadi 24,07. Sedangkan pada kelompok kontrol mengalami peningkatan dari 8,67 menjadi 8,87.

Untuk mengetahui adakah pengaruh signifikan antara dua variabel, dan untuk mengetahui perbedaan mean antara sebelum dan sesudah terapi glenn doman pada masing masing kelompok perlakuan dan kelompok kontrol maka dilakukan uji T-Test dependen, namun terlebih dahulu dilakukan uji normalitas untuk mengetahui apakah data terdistribusi normal atau tidak. Uji normalitas data pada penelitian ini mengguakanshapiro wilk- test, uji ini dilakukan karena sampel yang di teliti kurang dari atau sama dengan 50 (Sopiyuddin, 2014).

Tabel. 4

Hasil Uji T-Test Dependen tentang Perkembangan

Komunikasi pada Anak Autisme di Autis Centre Bengkulu

\begin{tabular}{|c|c|c|c|c|c|}
\hline Kelompok & Mean & Min-max & Standar Deviasi & $\begin{array}{c}\text { Standar } \\
\text { Error }\end{array}$ & Sig P value \\
\hline \multicolumn{6}{|c|}{ Kelompok Kontrol } \\
\hline Pengukuran I & 8,67 & $4-12$ & 2,257 & 0,583 & 0,647 \\
\hline Pengukuran II & 8,87 & $5-12$ & 1,995 & 0,515 & \\
\hline \multicolumn{6}{|c|}{ Kelompok Perlakuan } \\
\hline Pengukuran I & 14,53 & $12-17$ & 1,552 & 0,401 & 0,00 \\
\hline Pengukuran II & 24,07 & $21-26$ & 1,486 & 0,384 & \\
\hline
\end{tabular}

Berdasarkan tabel diatas diketahui rata-rata kemampuan bicara anak-anak autis sebelum diberi terapi glenn doman tahap 1 dan 2 adalah sebesar 14,53 dan setelah mendapatkan terapi glenn doman tahap 1 dan 2, kemampuan bicara anak autis mengalami peningkatan menjadi 24,07. Sedangkan pada kelompok kontrol mengalami peningkatan dari 8,67 menjadi 8,87 Berdasarkan tabel di atas diperoleh nilai p 0,000 pada kelompok perlakuan dan 0,467 pada kelompok kontrol. Dapat disimpulkan bahwa ada perbedaan kemampuan komunikasi antara kelompok kontrol dan kelompok perlakuan. 
Tabel. 5

Hasil Uji T-Test Independen tentang Perkembangan Komunikasi pada Anak Autisme di Autis Centre Bengkulu

\begin{tabular}{lllllll}
\hline & & Mean & SD & SE & p Value & N \\
\hline selisih & perlakuan & 9,53 & 2,031 & 0,524 & 0,000 & 15 \\
\hline & kontrol & 0,20 & 1,656 & 0,428 & 0,000 & 15 \\
\hline
\end{tabular}

Berdasarkan tabel diatas diketahui rata-rata kemampuan bicara anak-anak autis yang diberi terapi glenn doman ( kelompok perlakuan ) tahap 1 dan 2 adalah 9,53 dan kelompok kontrol atau kelompok yang tidak di berikan terapi glenn doman tahap 1 dan 2 nilai rata ratanya adalah 0,20 . Berdasarkan tabel di atas pada kelompok perlakuan dan pada kelompok kontrol memiliki nilai $p$ 0,000. Karena $\mathrm{p}$ value lebih kecil dari 0,05 makaDapat disimpulkan bahwa ada perbedaan kemampuan komunikasi antara kelompok kontrol dan kelompok perlakuan.

\section{PEMBAHASAN}

\section{Kemampuan Bicara Anak Autis Kelompok Kontrol dan Kelompok Perlakuan Sebelum Terapi Glenn Doman tahap 1 dan 2}

Penelitian ini dilaksanakan di Autis Center Bengkulu pada 30 responden yang dibagi dalam 2 kelompok yaitu kelompok kontrol dan kelompok perlakuan yang diberi terapi glenn doman tahap 1 dan 2. Pemilihan responden berdasarkan keaktifan responden mengikuti kegiatan di Autis Center. Sebelum diterapkan terapi glenn doman tahap 1 dan 2, peneliti mengukur kemampuan responden dalam melakukan kemampuan bicara yang meliputi tiga (3) kategori yaitu bahasa reseptif, bahasa ekspresif dan bahasa sosial. Hasil pengukuran kemampuan bicara sebelum diterapi glenn doman tahap 1 dan 2, responden rata-rata tidak memiliki kemampuan dalam melaksanakan keterampilan dasar. Hal ini ditunjukkan responden tidak mau bereaksi saat dipanggil namanya, tidak mampu menunjuk dengan kata-kata benda yang diinginkan, tidak dapat mengucapkan kata benda yang diminta, serta belum mampu menyebut nama-nama keluarga terdekat.

Pada penelitian ini, ketidakmampuan responden dalam melaksanakan kemampuan bicara dipengaruhi beberapa faktor, diantaranya dukungan keluarga dimana responden kurang mendapat dukungan keluarga, sang ibu kurang membimbing dan menstimulus anak dalam upaya meningkatkan kemampuan bicara anak. Usia menjadi salah satu faktor yang mempegaruhi tingkat keterampilan dasar responden, pada penelitian ini hampir sebagian responden berusia 3 tahun dengan jenis kelamin perempuan. Usia yang masih sangat kecil menyebabkan daya terima dan pemahaman responden kurang baik.

\section{Kemampuan Bicara Anak Autis Kelompok Kontrol dan Kelompok Perlakuan Sesudah Terapi Glenn Doman tahap 1 dan 2}

Berdasarkan hasil penelitian diketahui bahwa setelah dilakukan pengukuran tingkat kemampuan bicara responden sebelum dilakukan terapi glenn doman tahap 1 dan 2 pada kelompok kontrol dan kelompok perlakuan maka peneliti kemudian mulai melaksanakan program terapi glenn doman tahap 1 dan 2 kepada responden kelompok perlakuan selama 2 minggu. Pada penelitian ini bersama para terapis, responden diberi latihan-latihan bagaimana cara mengeja kosakata dan kalimat sederhana. 
Pada penelitian ini, setelah kelompok perlakuan mendapat terapi glenn doman tahap 1 dan 2, kemudian dilakukan pengukuran ulang kemampuan bicara pada kedua kelompok. Pada kelompok kontrol, hasil pengukuran kemampuan bicara menunjukkan tidak terdapat perubahan kemampuan bicara sedangkan pada kelompok perlakuan terapi glenn doman tahap 1 dan 2 terdapat perubahan peningkatan kemampuan bicara. Namun dari hasil pengukuran kemampuan bicara pada kelompok perlakuan masih ada sebagian kecil respoden yang memiliki sedikit kemampuan bicara hal ini dapat disebabkan anak sering diajak berinteraksi dengan lingkungan, sang ibu dan keluarga sering membawa anak mereka untuk bersosialisasi dengan lingkungan sekitar maupun lingkungan diluar sehingga anak menyerap beberapa kosakata dari sosialisasi tersebut. Di dalam rumah, anggota keluarga saling mendukung dan perduli dalam memberikan kasih sayang, selalu mengajari anak mereka agar mampu melakukan kemampuan bicara. Kemampuan bicara seorang anak juga dapat dipengaruhi oleh faktor biologis anak dimana faktor biologis anak yang satu dengan yang lainnya berbeda.

Hasil penelitian juga diketahui kemampuan bicara setelah dilakukan terapi glenn doman tahap 1 dan 2 menunjukkan bahwa responden yang mendapat terapi mengalami peningkatan kemampuan bicara. Hal ini terlihat dari responden yang sudah mampu bereaksi saat dipanggil, mampu menyebut nama-nama keluarga terdekatnya, dapat menyebutkan nama-nama benda yang ada dilingkungannya.

Hasil penelitian ini menunjukkan bahwa terapi glenn doman tahap 1 dan 2 memberikan dampak yang positif dalam perkembangan kemampuan bicara anak autis dimana seperti yang diketahui anak autisme diartikan sebagai anak yang mengalami gangguan berkomunikasi dan berinteraksi sosial serta mengalami gangguan sensoris, pola bermain dan emosi yang disebabkan jaringan dan fungsi otak tidak sinkron ada yang maju pesat, sedangkan yang lainnya biasa-biasa saja, dimana anak autis mengalami gangguan perkembangan dalam bidang komunikasi (berbicara dan berbahasa), interaksi sosial dan perilaku.

\section{Pengaruh Terapi Glenn Doman terhadap Perkembangan Komunikasi pada Anak Autisme di Autis Centre Bengkulu}

Hasil penelitian menunjukkan bahwa pada kedua kelompok penelitian yaitu kelompok kontrol dan kelompok perlakuan sebelum dilakukan terapi glenn doman tahap 1 dan 2, tingkat kemampuan bicara responden kurang. Pada kelompok kontrol kemampuan bicara anak autisme memiliki nilai rata-rata 8,67 sedangkan nilai rata-rata pada kelompok yang diberi terapi glenn doman tahap 1 dan 2 dapat dilihat dari nilai hasil pengukuran kemampuan bicara dengan nilai rata-rata 14,53.

Hasil pengukuran tingkat kemampuan bicara pada terapi glenn doman tahap 1 dan 2, responden dikatakan belum mampu dalam berbahasa. Ketidakmampuan responden dalam melakukan kemampuan bicara dikarenakan respoden belum mendapat latihan-latihan akan kemampuan bicara, dimana responden sangat sulit untuk dapat fokus pada suatu kegiatan atau sesuatu hal. Selain itu responden juga kurang mendapat latihan kemamuan bicara dari keluarga responden.

Pada penelitian ini, sesudah responden mendapat terapi glenn doman tahap 1 dan 2 diperoleh responden mengalami peningkatan keterampilan dasar dimana nilai kemampuannya rata-rata 24,07. Pada terapi glenn doman tahap 1 dan 2, responden diberi latihan-latihan dasar mengenai kosakata yang sederhana. Sedikitnya peningkatan kemampuan bicara pada penelitian ini dipengaruhi oleh waktu penelitian yang hanya kurang lebih sebulan. 
Sedangkan pada kelompok kontrol terdapat peningkatan kemampuan bicara hanya $2 \%$. Hal ini dikarenakan kelompok kontrol tidak mendapatkan perlakuan terapi atau latihan-latihan yang bertujuan untuk meningkatkan kemampuan bicara. peningkatan kemampuan bicara pada kelompok kontrolhanya sedikit dapat dilihat dari nilai rata rata yaitu 8,67 ke 8,87 .

Hasil penelitian dari uji statistik diperoleh nilai $\mathrm{p}=0,000$, berarti $\mathrm{p} \leq 0,05$ sehingga $\mathrm{H} 0$ ditolak yang berarti bahwa terdapat pengaruh terapi glenn doman tahap 1 dan 2 terhadap kemampuan bicara anak autis di Autis Center Bengkulu.

Hasil penelitian ini sejalan dengan penelitian yang dilakukan oleh Ragil Deshinta (2014) dengan judul pengaruh metode glenn doman terhadap kemampuan interaksi sosial anak autisme di SLB-B dan autisme TPA (Taman Pendidikan Dan Asuhan) Kabupaten Jember. Hasil penelitian menunjukkan bahwa terapi glenn doman memberikan pengaruh yang positif terhadap kemampuan interaksi sosial anak Autis di SLB-B.

Hasil penelitian ini diperkuat dengan penelitian Tiara Dwi yuniarti, dkk dengan judul Pengaruh metode glenn doman terhadap perkembangan bahasa dan kognitif anak usia prasekolah di TK Ladas Berendai Prabumulih, Pada penelitian ini mennunjukkan terdapat pengaruh yang signifikan terapi glenn doman terhadap perkembangan bahasa dan kognitif pada anak usia prasekolah.

\section{Perbedaan rata rata kemampuan perkembangan komunikasi pada kelompok perlakuan dan kelompok kontrol}

Berdasarkan hasil penelitian diketahui bahwa perbedaan rata rata pada kelompok kontrol dan kelompok perlakuan adalah rata rata lebih besar nilai rata rata perkembangan komunikasi pada kelompok perlakuan di banding nilai rata rata nilai pada kelompok kontrol yang tidak di berikan intervensi.Pada penelitian ini, setelah kelompok perlakuan mendapat terapi glenn doman tahap 1 dan 2, kemudian dilakukan pengukuran ulang kemampuan bicara pada kedua kelompok. Pada kelompok kontrol, hasil pengukuran kemampuan bicara menunjukkan tidak terdapat perubahan kemampuan bicara sedangkan pada kelompok perlakuan terapi glenn doman tahap 1 dan 2 terdapat perubahan peningkatan kemampuan bicara. Namun dari hasil pengukuran kemampuan bicara pada kelompok perlakuan masih ada sebagian kecil respoden yang memiliki sedikit kemampuan bicara Hasil penelitian juga diketahui kemampuan bicara setelah dilakukan terapi glenn doman tahap 1 dan 2 menunjukkan bahwa responden yang mendapat terapi mengalami peningkatan kemampuan bicara. Hal ini terlihat dari responden yang sudah mampu bereaksi saat dipanggil, mampu menyebut nama-nama keluarga terdekatnya, dapat menyebutkan nama-nama benda yang ada dilingkungannya. 


\section{SIMPULAN}

Berdasarkan hasil penelitian dan analisis data tentang pengaruh terapi perilaku glenn doman tahap 1 dan 2 terhadap kemampuan bicara anak autis umur 2-5 tahun di Autis Center Bengkulu, maka dapat ditarik simpulan sebagai berikut:

Kemampuan bicara responden pada kelompok kontrol dan kelompok perlakuan sebelum diberikan terapi glenn doman Tahap 1 dan 2 pada anak autisme di Autis Center Kota Bengkulu sebagian besar belum mampu.

Kemampuan bicara responden pada kelompok kontrol dan kelompok perlakuan sesudah diberikan terapi glenn doman Tahap 1 dan 2 pada anak autisme di Autis Center Kota Bengkulu seluruhnya masuk dalam kategori mampu sedangkan pada kelompok kontrol mengalami peningkatan hanya $2 \%$.

Terapi glenn doman Tahap 1 dan 2 efektif terhadap perkembangan bicara pada anak autisme di Autis Center Kota Bengkulu.

\section{SARAN}

1. Teoritis. Hasil penelitian dapat bermanfaat untuk menambah wawasan, serta dapat mengatahui seberapa besar pengaruh terapi prilaku glenn doman tahap 1 dan 2 terhadap kemampuan wicara pada anak autis.

2. Praktis. Hendaknya Autis Center Bengkulu dapat meningkatkan metode glenn doman tahap 1 dan 2 sehingga kemampuan bicara anak autis dapat lebih cepat berkembang.

3. Peneliti. Hendaknya untuk peneliti selanjutnya menggunakan metode glenn doman ini sampai tahap ke lima dengan menngunakan kelompok kontrol dengan waktu lebih dari dua minggu.

\section{DAFTAR PUSTAKA}

Adriana, D. (2010). Tumbuh Kembang dan Terapi Bermain pada Anak. Jakarta: Salemba Medika

Ahmadi, F. (2010). Meningkatkan Minat Membaca Siswa Sekolah Dasar dengan Metode Glenn Doman Berbasis Multimedia. Jurnal Penelitian Pendidikan, 27(1) Tahun 2010 PGSD FIP UNNES

Alit S, I.G.A. (2011). Model Komunikasi Penangan Anak Autisme melalui Terapi Bicara Metode Lovaas. Skripsi

Arikunto, S. (2010). Prosedur Penelitian Suatu Pendekatan Praktik. Jakarta: Rineka Cipta

Asmani, J. (2009). Manajemen Strategi Pendidikan Anak Usia Dini (PAUD). Yogyakarta: Diva Press

Aulia. (2011). Mengajarkan Balita Anda Membaca. Yogyakarta: Intan Media

Bethsaida, J., \& Herri, Z. P. (2013). Pendidikan Psikologi untuk Bidan Suatu Teori dan Terapannya. Edisi 1. Yogyakarta: Rapha Publishing

Delphie, B. (2006). Pendidikan Anak Autis. Sleman: PT. Intan Sejati Klaten

Doman, G. dan Doman, J. (2006). How to Teach Your Baby to Read: Bagaimana Mengajar Bayi Anda Membaca (Alih Bahasa: Grace Satyadi). Jakarta:Tigaraksa Satria

Faisal Yatim DTM. (2003). Autisme Suatu Gangguan Jiwa pada Anak-anak. Jakarta: Pustaka Populer Obor

Galih A. V. (2008). 12 Terapi Autis Paling Efektif dan Hemat. Jakarta Buku Kita 
Gordon. (2010). Meningkatkan Keterampilan Komunikasi pada Anak Autis. Yogyakarta: Pustaka Pelajar

Handojo.(2008). Autisma: Petunjuk Praktis dan Pedoman Materi Mengajar untuk Anak Normal, Autis dan Perilaku Lain. Jakarta: PT. Bhuana Ilmu Populer

Herri. (2011). Berbicara Sebagai Suatu Keterampilan Berbahasa. Bandung: Angkasa

Hidayat, A., A. (2005). Ilmu Kesehatan Anak. Jakarta: Salemba Medika

Jordan \& Powell. (2002). Understanding and Teaching Children with Autism. West Suswx England: John Wiley and Sond Ltd

Kemenkes. (2010). Mari Kenali dan Peduli terhadap Anak Autis. Jakarta: Kemenkes

Kusumawati \& Hartono. (2010). Buku Ajar Keperawatn Jiwa. Jakarta: Salemba Merdika

Mariana, D., Wulandari, D., \& Padila, P. (2018). Hubungan Pola Makan dengan Kejadian Anemia pada Ibu Hamil di Wilayah Kerja Puskesmas. Jurnal $\begin{array}{lll}\text { Keperawatan } & \text { Silampari, } & 1(2),\end{array}$ https://doi.org/https://doi.org/10.31539/jks.v1i2.83

Masitoh. (2003). Model Pembelajaran Bahasa Berdasarkan Pendekatan Bahasa Menyeluruh (Whole language approach) di TK. Tesis UPI Bandung. Tidak Diterbitkan

Miller, M.S. (2011). Bringing Learning Home. New York: Happer \& Row Publish

Mirza, M. (2010). Anak Autis, Mendidik Anak Autis dan Gangguan Mental Lain Menuju Anak Cerdas dan Sehat. Jogjakarta

Olivia. (2009). Belajar Membaca yang Menyenangkan Untuk Usia Dini. Jakarta: PT.Elex media Komputindo

Padila, P., Amin, M., \& Rizki, R. (2018). Pengalaman Ibu dalam Merawat Bayi Preterm yang Pernah dirawat di Ruang Neonatus Intensive Care Unit Kota $\begin{array}{llll}\text { Bengkulu.Jurnal Keperawatan } \quad \text { Silampari, } & \text { 1(2), }\end{array}$ https://doi.org/https://doi.org/10.31539/jks.v1i2.82

Pertamawati, N. (2008). Penerapan Metode Glenn Doman untuk Meningkatkan Kemampuan Membaca Anak yang Memiliki Gangguan Cerebral Palsy. [Skripsi]. Malang: Universitas Islam Negeri Maulana Malik Ibrahim

Ragil D. (2015). Pengaruh Metode Glenn Doman terhadap Kemampuan Interaksi Sosial Anak Autisme di SLB-B dan Autisme TPA (Taman Pendidikan dan Asuhan) Kabupaten Jember. e-Jurnal Pustaka Kesehatan, 3(1)

Rani. (2014). Pengaruh Metode Glenn Doman dalam Meningkatkan Kemampuan Menyimak dan Membaca Anak Usia Dini (Studi Eksperimen Kuasi pada Anak Usia 4-5 Tahun di Tk Bukit Dago Bandung). Universitas Pendidikan Indonesia

Rohman. (2010). Peran Glenn Doman sebagai Metode Pembelajaran Membaca Pada Anak yang Mengalami Cedera Otak

Sugiyono. (2013). Metode Penelitian Kuantitatif Kualitatif dan R\&D. Bandung: Alfabeta

Sunaryo. (2006). Intervensi Dini Anak Berkebutuhan Khusus. Jakarta: Dirjen Dikti Depdiknas

Surana \& Taufan. (2008). Bagaimana Flashcards dan Dotcards Mampu Meningkatkan Kecerdasan Anak dalam Balita Cerdas.com. http://info.balitacerdas.com

Tiara DY. (2013). Pengaruh MEtode Glenn Doman terhadap Perkembangan Bahasa dan KOgnitif Anak Usia Prasekolah di TK Ladas Berendai Prabumulih

Unesco. (2011). Retrieved from https://klinikautis.com/2015/09/06/jumlahpenderitaautis-di-indonesia/ 
Widihastuti, S. (2012). Pola Pendidikan Anak Autis. Yogyakarta: FNAC Press Widihastuti. (2009). Autis pada Anak. Yogyakarta: Nuha Medika

World Health Organization (WHO). (2015). Global Autism Report 2015. Switzerland Wulandari R. (2013). Teknik Mengajar Siswa dengan Gangguan Bicara dan Bahasa. Panduan untuk Guru. Yogyakarta: Imperium

Yuwono J. (2009). Memahami Anak Autistik: Kajian Teoritik dan Empirik. Bandung: Alfabeta 